SEER now NCEEER). In the early 1980s, Herb used his considerable influence with academic and scholarly communities to provide major assistance in the creation of the Title VIII legislation that has helped sustain federal support for advanced research on the former Soviet Union and central and eastern Europe for more than twenty years.

Herb also served as NCSEER's scholarly liaison to the Soviet Interview Project, an undertaking that opened major methodological vistas for American scholars of Russia, making them far more prepared for the fall of the Soviet Union and the opportunities for implementing advanced social science methods that followed. He also played a key role in the creation of the New Economic School in Moscow, where Mikhail Gorbachev and postSoviet era economists help to train a new generation of Russian economists.

A first-rate economist, first-rate research scholar, and first-rate administrator and fundraiser, Herb was above all a first-rate human being. And whether at the macro-level issues of field building or the micro-level issues of training students, Herb was uniquely the same: teacher, mentor, colleague, and friend.

\author{
ROBERT T. HUBER \\ National Council for Eurasian and East European Research \\ January 2008
}

\title{
Thomas D. Marzik, 1941-2007
}

Thomas D. Marzik died peacefully at his home in Merion Station, Pennsylvania, with his wife Hana by his side, on 23 October 2007, after a long, valiant struggle against cancer and other ailments. Born in Bridgeport, Connecticut, on 15 December 1941, Tom attended Fairfield College Preparatory School and the College of the Holy Cross, where, after spending his junior year at the University of Vienna, he graduated with a BA degree magna cum laude in 1963. At Columbia University, he earned an MA in 1968 and a PhD in 1974 under the guidance of István Deák. From 1970 until his death, he was a faculty member of the Department of History of St. Joseph's University, where he taught courses in western civilization and the history of Russia and honors seminars in European history. A loyal band of students came to respect his rigorous standards of accuracy and exposition in writing and oral expression.

Tom's meticulousness served the scholarly world well in what is his most important and lasting contribution to the field of Czech and Slovak history, the two-volume work, R. W. Seton-Watson and His Relations with the Czechs and Slovaks: Documents, 1906-1951 (Prague, 1995-1996), which he co-edited with Jan Rychlik and Miroslav Bielik.

Early in his career, Tom became interested in T. G. Masaryk, the founding father of the modern Czechoslovak state. His early essay, "T. G. Masaryk and the Slovaks, 18821914," in Andrew W. Cordier, ed., Columbia Essays in International Affairs: The Dean's Papers, 1965 (New York, 1966), was followed by "Masaryk's National Background," in Peter Brock and H. Gordon Skilling, eds., The Czech National Renascence of the Nineteenth Century: Essays Presented to Otakar Odlozilik in Honour of His Seventieth Birthday (Toronto, 1970) and "The Slovakophile Relationship of T. G. Masaryk and Karel Kálal prior to 1914," in Stanley B. Winters, ed., T. G. Masaryk (1850-1937), Vol. 1, Thinker and Politician (London, 1990). Tom pursued this interest into the next generation, focusing on Masaryk's son Jan, who would later serve as foreign minister of Czechoslovakia. Using documents he found in the United States, including Jan Masaryk's medical records, Tom published three articles in the Czech Republic on Jan Masaryk's stay in America. In other articles published in the Czech Republic, Slovakia, and Poland, Tom surveyed the state of American scholarship concerning Czechs and Slovaks in the United States.

Tom excelled in and will be remembered for his service to the profession and to others in the United States, Slovakia, and the Czech Republic. A founding member of the Slovak Studies Association, he served as its vice president and later as its treasurer. He also served a term as vice president of the Czechoslovak History Conference and as a member 
of its executive committee. From 1981 to 1991 he was book review editor for Slovak books at East Central Europe.

Following the fall of communism in east central Europe, Tom's involvement with the academic world of Slovakia and the Czech Republic intensified. He served as an editorial correspondent for the Masaryk Institute of the Czech Academy of Sciences. At the time of his death, he had recently been appointed the American administrator of the agreement on cooperation between St. Joseph's University and the Masaryk Institute of the Czech Academy of Sciences, the first such agreement between the Masaryk Institute and a North American academic institution. In 1998 the president of Slovakia honored him with a medal for his contributions to the history of Slovaks and Slovakia. Informally, Tom was well known for selflessly sending colleagues in both the United States and central Europe materials related to their research and interests, all addressed in a penmanship that would make a grade-school nun proud, always in ink, never in ballpoint.

An ebullient raconteur, Tom had a dry sense of humor, and he would occasionally punctuate his tales with an unrestrained raucous laugh. He knew the oeuvre of W. C. Fields well enough to interject an appropriate bon mot at the most depressing moment. Arriving just days before the Soviet bloc invaded Czechoslovakia on 21 August 1968, I visited him in Prague, where he was doing research for his dissertation. As we watched the Soviet tanks from the windows of his apartment, he turned to me and said, "Philadelphia would do!"- from the film My Little Chickadee in which the character played by W.C. Fields when faced with a lynch mob says, "I'd like to see Paris before I die ... Philadelphia would do."

Philadelphia did do. In addition to his wife Hana, Tom is survived by his brother Robert and his family. He is missed by his many friends, colleagues, and former students. "Those you love take away a part of you, the self you were with them" (Colin Thubron, Shadow of the Silk Road, 2007).

JoHN J. KuLCZYCKI

University of Illinois, Chicago

January 2008 